\title{
Soome-ugri muinastaide mõistest ja taieste liigitamisest
}

Enn Ernits

\section{Soome-ugri (alade) muinastaide mõiste}

Taie ehk kunst laiemas mõistes hõlmab sõna-, heli-, tantsu-, ehitus-, tarbe-, dekoratiiv- ja kujutavat kunsti, kitsamas mõistes aga üksnes nelja viimast, hõlmates seega plaankommunikatsiooni visuaalsete vahenditega. Muinas- ehk esiaegset väga iidset kunstiloomet nimetatakse muinastaideks. Saksamaalt Hamburgi kandist on leitud kivikujukesi, mille vanuseks arvatakse enam kui 100000 aastat. Tõsi küll, enamik uurijaid peab neid looduse vormituks. Kindlasti viljeles kunsti paleoliitikumi ehk vanema kiviaja inimene ligikaudu 40000 aasta eest.

Kunsti teket kauges minevikus on seletatud mitmeti. Siinkirjutaja nõustub nende uurijatega, kes oletavad, et ürginimese vaimses kultuuris kuulusid ühte religioon ning hilisema kunsti ja teaduse alged (Kangilaski 1997: 25). See võimaldab eristada ürgajal eksisteerinud religiooni, kunsti ja teaduste diferentseerumata, sünkretistliku alget, mis pakub huvi nii usundiloo, kunstiajaloo kui ka üksikute teadusharude (näiteks anatoomia, arheoloogia) ajaloo uurijatele.

Muinasaegseid esemeid on uurinud nii arheoloogid kui ka kunstiajaloolased. Arheoloogidel on kogu universaalsuse juures raske kõigile, nii vaimse kui ka materiaalse elu tahkudele võrdset tähelepanu osutada. Arheoloogiast erineb mõnede muinastaide liikide, nt kaljutaide dokumenteerimise, dateerimise, identifitseerimise ja interpreteerimise metoodika. Tunduvalt lähemal on kunstiajaloolased, kuid muinastaie on siiski üsna spetsiifiline ala, mille uurimine eeldab ka arheoloogia, usundiloo, bioloogia jm põhjalikku tundmist.

Eeltoodut arvestades on otstarbekas eristada muinastaiet uuriv teadus iseseisvaks distsipliiniks nimetusega muinastaideteadus. Liiatigi arvestades, et kaljutaide uurijad on üritanud eristada kaljutaideteadust mitmesuguste nimetuste all (nagu pefoloogia, petroikonoloogia jt) omaette teadusharuks, arvestamata paraku muinastaide kui tervikuga. 
Soomeugrilased elavad idas Skandinaaviast Lääne-Siberini ja lõunas Doonau kallasteni. Nende hulka kuuluvad läänemeresoomlased (liivlased, eestlased, vadjalased, soomlased, karjalased, vepslased jt), saamid, mordvalased, marid, permid (komid ja udmurdid), obi-ugrilased (handid, mansid), ungarlased. Soome-ugri muinastaie hõlmab asjaomaste rahvaste ja alade taiet paleoliitikumist kuni kirjutatud ajaloo alguseni, mis näiteks eestlastel algas XIII sajandi alguses, kuid pisematel soome-ugri hõimudel mitu aastasada hiljem. Muinastaideteadust huvitavad ka hilisemad taiesed, kui neil on mingisugust seost esiajaga.

Mis tahes piirkonna paleoliitikumi elanikkonna seostamine soomeugrilaste esivanematega on enam kui kahtlane. Igatahes on usutav, et soomeugrilaste muinaskultuuri mõjustajateks võisid olla igijää piiride lähedal elanud paleoliitilised hõimud. Sellele on näiteks osutatud Uuralis leiduvate Kapova koopamaalingute ja sealse piirkonna hilisema taide võrdleval uurimisel. Ega hilisemategi kiviaja perioodide hõimude identifitseerimine tänapäeva rahvastega ole alati selge, eriti piirialadel. Seepärast on otstarbekas kasutada kiviaja taide kirjeldamisel soome-ugri (endiste ja praeguste) alade taide mõistet ning jätta selle ühendamine konkreetsete etnostega tuleviku ülesandeks.

Soome-ugri muinastaiet saab mõista kaheti, nimelt 1) soomeugri algkeele perioodi taidena, sõltumata sellest, kui kestvaks vähediferentseerunud algkeele eksisteerimise aega pidada, ja 2) soomeugri üksikrahvaste või -rühmade taidena kogu muinasajal, s.o alates kiviajast kuni nende hõimude võõrvallutajate poolt alistamise ja ümberusustamiseni (ristiusk, islam). Näiteks võib eristada ühelt poolt eesti, vadja, komi, ungari muinastaiet, teisalt aga läänemeresoome, permi, obi-ugri jne muinastaiet.

\section{Soome-ugri muinastaieste liigitamine}

Muinastaide objekte on võimalik klassifitseerida mitmesugustest alustest (materjal, tehnika, funktsioonid jne) lähtuvalt. Sageli põimuvad erinevad klassifikatsioonid omavahel ning on tihedas seoses materiaalse kultuuri (rakendusfunktsiooni kaudu) ja usundiga. Seepärast saab üht ja sama eset sageli liigitada mitmeti. 
Tegelikult võib kõike muinasajal inimkäega valmistatut pidada taiesteks, olgu see siis merevaigust kujuke, savipott, kivikirves või peakate. Kuid nende kunstipärasuse hindamine on erinev. Tööriistal või tarbeesemel peame silmas esmajoones selle väliskuju. Seevastu näiteks skulptuuril või maalingul pole materiaalset funktsiooni, ta kätkeb endas religioosset vms ideed. Selliseid esemeid hindame kunstipärasuse seisukohast tunduvalt kõrgemalt. Seega võiks eristada muinastaieseid laiemas ja kitsamas mõistes.

Käesolevas kirjutises üritatakse klassifitseerida soome-ugri rahvaste ja alade muinastaieseid ning üldjoontes peaks see liigitus kehtima ka teiste hõimude (alade) kohta. Autor on teadlik, et esmakatse pole ideaalne ja loodab, et järgnevad käsitelud aitavad üldpilti täpsustada.

Muinastaideteadust huvitavad kõik ürginimese valmistatud objektid. Need võib jagada kolmeks suureks rühmaks:

1) kujutavad muinastaiesed,

2) muinasehitustaiesed ehk muinasrajatised,

3) igasugused tarbeesemed.

Esimest liiki käsitletakse muinastaiestena kitsamas mõistes. Hoonete ehitamine seondub muinasarhitektuuriga. Kõikvõimalike tarbeesemete (rõivad, nõud, relvad jne) valmistamises saab näha tarbe- ja moekunsti algeid. Hoone rajamine ja esemete vormimine on toimunud ilmselt funktsioonist, materjalist ja stereotüüpsusest lähtuvalt käsikäes kunstioskuste arenemisega. Kolmandas rühmas saab käsitleda töö- ja tarberiistu (keraamilised, puu- ja kivinõud), sõiduvahendeid, relvi, rõivaid jm. Muinastaide seisukohalt pakub huvi nende kuju. Teist ja kolmandat liiki esemeid võib nimetada muinastaiesteks laiemas mõistes. Laiemas mõistes kuuluvad muinastaieste hulka näiteks savinõud ja Suomusjärve kultuurile iseloomulik ümmargune kivinui, kitsamas mõistes on kunstipärane vaid nende ornament.

Käesolev kirjutis keskendub kaht esimest põhiliiki muinastaieste edasisele klassifitseerimisele, kusjuures suuremat tähelepanu osutatakse valmistamistehnikast johtuvale liigitamisele. Taieseid saab jaotada muidugi ka materjalist, temaatikast ja teistest alustest lähtuvalt. Igatahes jääb temaatiline liigitamine käesoleva vaatluse raamidest välja. 


\subsection{Kujutavad muinastaiesed}

Tänapäevane kunsti jaotamine kujutavaks ja tarbekunstiks ei sobi muinastaide kirjeldamiseks, sest need olid muinasajal veel diferentseerumata. Kujutavad muinastaiesed seonduvad kujutistega, mida võib jagada 1) figuraalseteks ja 2) mittefiguraalseteks ehk kujunditeks.

Figuraalsed on kujutised (sisulises mõttes motiivid), mis kajastavad elusolendeid (inimesed, loomad, taimed) või eluta esemeid (esineb harva). Praktikas eristatakse inimese, looma-, linnu-, puu-, mõõga-jne figuure. Sel puhul on eristav vähemalt kujutatud olendi või eseme väline piirjoon ehk figuur. Kuna pole selge, kas kujutatud inimene või loom tähistab reaalset inimest või looma või hoopis inimese- või loomakujulist jumalust, on mõttekas kasutada mõisteid, nagu inimeselaadne kujutis ehk antropomorf, loomalaadne ehk zoomorf, imetajalaadne ehk teriomorf, hobuselaadne ehk hipomorf, linnulaadne ehk ornitomorf, maolaadne ehk ofiomorf jne (vt lähemalt Poikalainen \& Ernits 1998: 7-8, 50).

Mittefiguraalsete kujutiste hulka kuuluvad peale ebamäärase vormiga kujutiste peamiselt geomeetrilised kujutised, mis koosnevad geomeetrilistest elementidest (joontest, ringidest, spiraali-

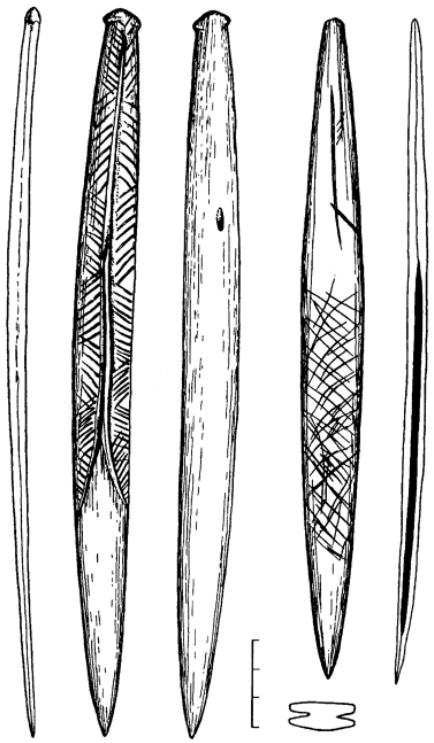
dest, kolmnurkadest jne). Enamasti moodustavad sellised korduvad elemendid ornamendi (joonis 1). Geomeetrilise ornamendi figuraalne lähe, mida on püütud tõestada, pole veel usutavasti selgitatud. Küll võivad figuuridest olla tekkinud sümbolkujutised ehk sümbolid. Ornament võib koosneda ka figuraalelementidest (linnud, taimelehed jm).

Sageli tuleb eristada, kas kogu ese on taies (nt karufiguur) või on seda vaid mõni osa (nt ornamenteeritud luunaaskel või mõõga käe-

Joonis 1. Geomeetriline ornament keskmise kiviaja torkerelvadel Veretjest Arhangelski oblastist (Ošibkina 1997: 131). 
pide). Esimesel juhul on tegu täis- ehk totaaltaiesega, viimasel juhul võib rääkida osa- ehk partsiaaltaiesest.

Kui taiese valmistamisel on kasutatud üht tehnikat, on tegu lihttaiesega. Kui selle loomisel on rakendatud mitut viisi, siis räägime liittaiesest. Viimased on sageli ka mitmeosalised, koosnedes näiteks mulgustatud plaatjast põhiosast, ketikestest, kuljustest jm. Siinkohal võiks mainida soome-ugri rahvaste kõlisevaid ripatseid (vt ruumilised taiesed).

Suuruse alusel võib vajaduse korral eristada kaht vastandlikku rühma: 1) monumentaal-ja 2) pisitaiesed. Viimaseid on kirjanduses nimetatud ka mobiil- ehk portatiivtaiesteks. Kujutamise täpsuse astme ja kunstiliste taotluste alusel võib eristada ühelt poolt ülirealistlikke ehk naturalistlikke, realistlikke ja stiliseeritud figuure, teisalt aga detailiseeritud (detail-) ja skemaatilisi (skeem-) kujutisi.

Muinastaieseid saab jagada selle järgi, kas nad on tehtud tasapinnale (kujutise vähese sügavuse või kõrguse tõttu on nad tegelikult kahemõõtmelised) või on nad selgesti tajutavalt kolmemõõtmelised. Seega jagame kujutavad muinastaiesed kõigepealt kaheks suureks rühmaks:

1) tasapinnalised ehk lametaiesed,

2) ruumilised ehk ruumtaiesed.

Viimastele tehti sageli ka peaaegu tasapinnalisi kujutisi. Olgu selle näiteks savinõude ornamentika. Tasapinnalised ja ruumilised taiesed on kaks teineteisest väga erinevat alarühma. Seepärast liigitatakse neid erinevatel alustel.

I. TASAPINNALISTE EHK LAMETAIESTE klassifitseerimise aluseks on võetud peamiselt valmistamistehnika. Tasapinnaliste taieste alla kuuluvad:

1. Aditiivtaiesed:

1) maalingud ehk maaltaiesed,

2) joonistused ehk joonistustaiesed,

3) aplikatiivtaiesed.

2. Ekstraktiiv- ehk süvendtaiesed:

1) raiendid ehk raidtaiesed,

2) uurendid ehk uuristaiesed,

3) lihvindid ehk lihvtaiesed,

4) vajutustaiesed.

3. Riidekoe- ehk tekstiiltaiesed.

4. Tätoveeringud. 
1.Aditiivtaiesteks nimetame taieseid, mille valmistamisel on neile lisatud ainet, nt värvi pindadele või teistsuguseid riide- ja naharibasid riide- või nahkesemetele. Aditiiv-ja ekstraktiivtaieste mõiste aitas siinkirjutajal kasutusele võtta Flood (1997), kes oli neid kasutatud üksnes kaljutaide vallas.

Maalingud (terminoloogilise ühtluse mõttes võiks eesti keeles kasutada ka maalindi nimetust) on märja värvipigmendiga kivile, kaljule, puidule (ka kasetohule), nahale, keraamikale ja metallidele tehtud taiesed. Näiteks Mezinist on leitud suurtele mammutiluudele tehtud ornamentikat; asjaomaseid esemeid peetakse paleoliitilisteks muusikariistadeks (PSSSR 1984: 231).

Maalingute rühma kuuluvad ka ihule tehtud rituaalsed ja sõjamaalingud. Maalitavast substraadist lähtudes saab kõnelda kalju-, seina-, puu- ja kehamaalinguist. Kehale, nõudele ja mujale maalitud kujutised võivad tegelikkuses olla muidugi ka kumer- või nõguspinnalised. Maalingud võivad olla nii siluetsed kui ka kontuursed. Kasutades kehaosi (käsi, jalg) pinna värvimisel, on tegu jäljendehk imitatiivtaiesega, mis jaguneb positiiv-ja negatiivjäljenditeks. Esimesel juhul on siluettkujutis tekkinud värvise kehaosa kaljule vajutamisel, teisel juhul on see olnud kehaosa šablooniks kaljule ja värvitud seda ümbritsevale kaljuosale ilmselt suuga värvaine vesilahust pritsides.

Maalimine sai alguse paleoliitikumis. Eriti väärtuslikud on tõenäoliselt pühamuna kasutatud koobaste seintele ja lagedele ookri, musta pigmendi või söega tehtud kujutised - koopamaalingud. Soome-ugri aladel leiduvad koopamaalingud Uurali lõunaosas (Kapova, Ignatijevka ja Serpijevka koopas), kus on vanemal kiviajal kujutatud mammuteid, metshobuseid, ninasarvikuid, geomeetrilisi ornamente, inimesi (vt joonised 37-46 eelmises artiklis). LõunaUuralist on seni avastatud 25 kaljumaalingut, mis pärinevad noorema kiviaja ja varase keskaja vahelisest perioodist. Neist 17 asetsevad Ai ja Jürüzani jõe kallastel. Kesk-Uuralis Jekaterinburgist põhja pool on leitud kaljutaiet Irbiti, Tagili, Višera jt jõgede kallastelt, kokku 30 leiuala.

Soomest on leitud arvukalt nooremal kiviajal vertikaalsetele kaljuseintele maalitud kujutisi. Muistseid ookriga tehtud figuure on leitud ka Koolast Rõbatšii poolsaarelt, Norrast ja Rootsist. Võimalik, et muinasajal maaliti ka puidule ja teistele suhteliselt kiiresti hävivate materjalidele. 
Joonistusteks nimetatakse kuiva värvipigmendiga tehtud kujutisi. Maalingud ja joonistused moodustavad pigment- ehk värvitaieste rühma.

Aplikatiivtaiesteks nimetatakse pinnakaunistusega taieseid, mille kujutised on moodustatud esemele kinnitatud riide- ja nahatükikestest, helmeist vms. Teatavasti kinnitati muinasajal helmeid rõivaste kaunistuseks.

2. Ektraktiivtaiesteks nimetatakse taieseid, mis on saadud neilt pinnaosade eemaldamise tulemusel. Kujutisi saab valmistada sõltuvalt eesmärgist ja materjali kõvadusest pinna täksimise, lihvimise ehk abrasiooni, uuristamise, vajutamise, mulgustamise ehk perforeerimise vms teel.

Raiendid, uurendid ja lihvindid on raiumise, kriipimise, täksimise, uuristamise, lihvimisega kõvasse materjalisse (kivi, kaljumassiiv) süvendatud taiesed. Täksimine kujutab endast väikeste täkete tegemist kaljule vahetult kõva riistaga kopsides või haamer-peitel-meetodil. Kõvale materjalile, sh metallile figuraalse või ornamentaalse kujutise tegemist nimetatakse graveerimiseks. Käesolevasse rühma kuuluvad näiteks paleoliitikumist pärit luuplaadikesed põiksälkudest ornamendiga ühest asulast Permi lähedal ja Prikamjes rauaajal kivisse tehtud kujutised (RSFSR 1971: 304, 496). Samas rühmas võib esitada ka maride ja muromlaste aladelt leitud noorema rauaaja pronksliudu graveeritud ornamentaalsete, harvem figuraalsete kujutistega (Rudenko 1996).

Suurt huvi pakuvad teadusele kaljudesse süvendatud, kuid tavaliselt suhteliselt madalad kujutised, mida nimetatakse petroglüüfideks ehk eesti keeles sagedamini traditsiooniliselt kaljujoonisteks, mis pole sugugi õnnestunud nimetus. Nendest on kõige lihtsamad ohvri- ja lohukivid oma siledapõhjaliste lohkudega. Neid leidub paljudes piirkondades, Skandinaavias sageli koos figuraaltaiestega. Eestis on seni registreeritud üle 1700 lohukivi (Tvauri 1999: 115119). Petroglüüfide hulgas saab valmistamistehnika alusel eristada kaljuraiendeid, -uurendeid ja -lihvindeid.

Eristatakse vertikaalset ja horisontaalset kaljutaiet: esimesel juhul on kujutised tehtud püstkaljudele, teisel juhul aga horisontaalsetele pindadele. Kaljumaalinguid ja -raiendeid uurib kaljutaideteadus.

Soome-ugri alade kaljuraiendid on levinud Põhja-Skandinaaviast Lääne-Siberini (vt lähemalt Poikalainen \& Ernits 1996). Skan- 


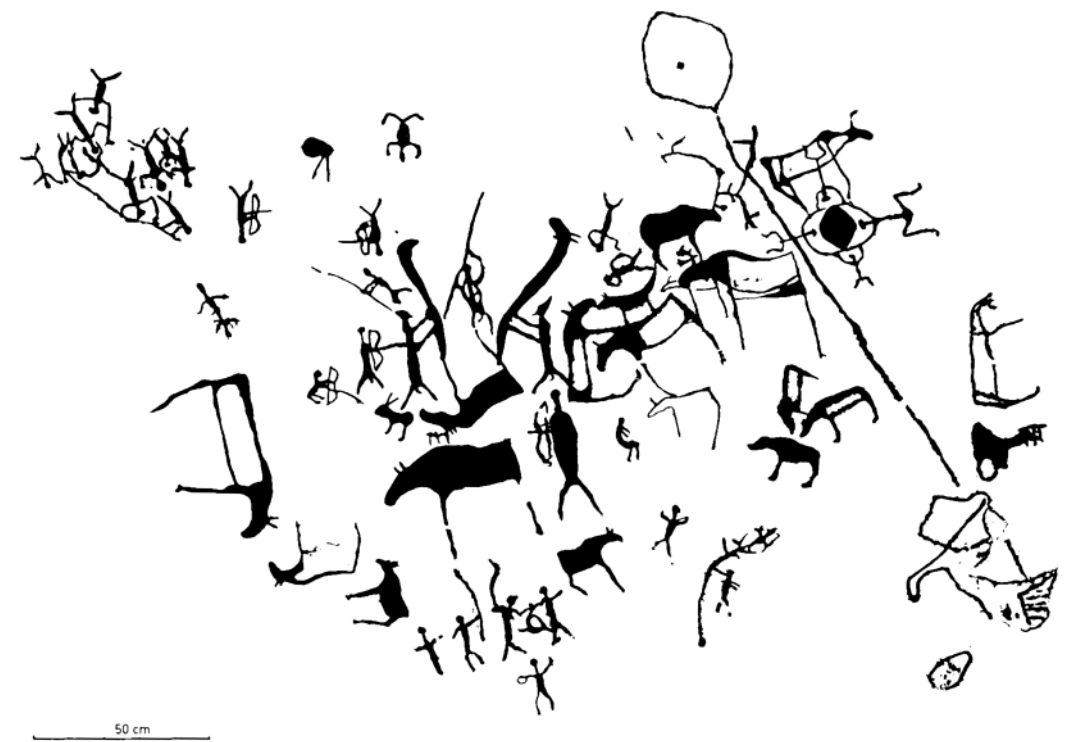

Joonis 2. Rühm neoliitilisi Alta kaljuraiendeid (Helskog 1994: 21).

dinaavia muinasaja küttide ja kalurite petroglüüfid arvatakse olevat saamide esiisade loodud. Tähtsamad leiukohad on PõhjaRootsis Nämforsen ning Põhja-Norras Alta (joonis 2).

Karjalas paiknevad suuremad kaljutaidealad Valge mere ääres Võgi jõe (Uikujoki) suudmes ja Äänisjärve idarannikul (joonis 3). Arhangelski oblastis on kujutisi uuristatud Pinega lisajõe äärsesse lubjakivvi.

Koola poolsaare keskosast Ponoi jõe äärsetelt kaljudelt endise saami küla Tšalmne-Varri juures ja poolsaare lõunaosast Kanozerolt on viimastel aastakümnetel leitud arvukalt petroglüüfe.

Lääne-Siberis leidub kaljutaiet Tomi jõe ääres Kemerovo ja Tomski vahel - kokku üle 600 kujutise.

Vajutustaiesed valmivad pehmesse materjalisse vajutamise tagajärjel, näiteks savinõude muster, mis on tekkinud kas sõrme, pulga, kalaluude või jämeda riidekoega vajutamisel; nõu põletatati seejärel ajale vastupidavaks. Soome-ugri keraamikataiestel esineb nii geomeetrilist ornamenti kui ka veelindude, inimeste jm figuure (joonis 4). Kujutisi võidi sõrme, varba või mõne esemega 


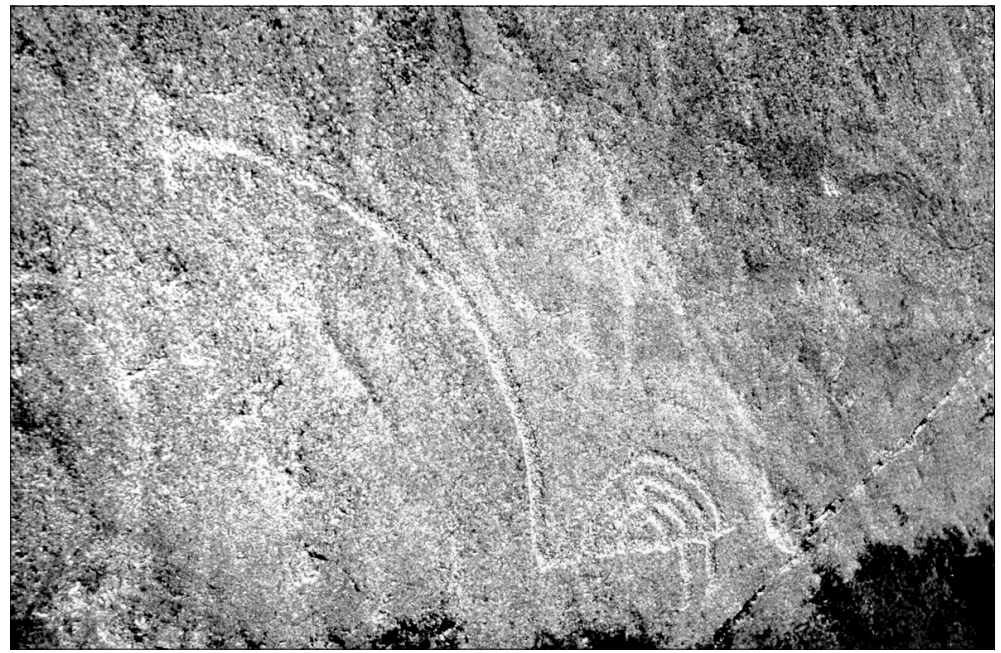

Joonis 3. Kaljuraiend Bessi neemelt Ä̈̈nisjärve leiukohast. E. Ernitsa foto.

Joonis 4. Karjalast leitud lohkkammkeraamika savinõude rekonstruktsioone (Pankrušev 1978: joonis 48).

vajutada ka maapinda ja pehmesse liivakivvi, kuid need hävisid üpris kiiresti.

\section{Riidekoe- ehk tekstiiltaiesed} valmistati kudumise, punumise vms teel. Näiteks Eestis on tekstiilkeraamika vahendusel teateid kudumitest hilisneoliitikumist alates
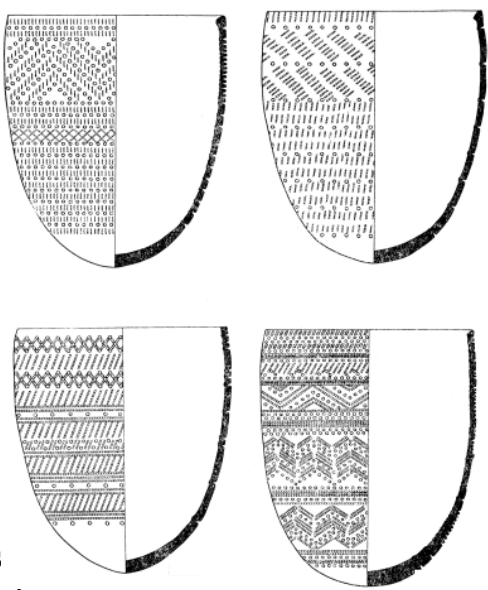
kasutati mitmesugust valmistamistehnikat (vt Selirand 1975: 17). Kangasse tehti ka mitmesuguseid mustreid. Sellesse taiesterühma ei kuulu võimalikud riidele värviga tehtud kujutised.

4. Tätoveeringud on eriline taieseliik, mis tehti inimkehale torketehnika ja värvidega. 
II. RUUMILISTE EHK RUUMTAIESTE rühm ühendab väga erilaadseid taieseid, mille hulka kuuluvad:

1. Skulptuur-, plastikataiesed ehk skulptuurid,

1) ümarskulptuurid ehk -taiesed,

2) reljeefid ehk reljeeftaiesed,

3) plaattaiesed.

2. (Ruumilised) mitteskulptuurtaiesed.

Tasapinnaliste ja ruumiliste taieste detailsema liigitamise põhialusteks on nende erinev valmistamistehnika ja osaliselt ka funktsioon. Ruumiliste taieste materjal on olnud väga erinev ja neil võib esineda ka lametaieste elemente. Näiteks Narva lähedalt Tõrvalast on leitud põdrasarvest maokuju, mille seljale on tehtud rästikule iseloomulik siksakjoon, küljele aga ilmselt soomuseid imiteeriv auguline muster. Varajase kammkeraamika perioodist pärinevad Soomest jm pisikesed savist antropomorfid, mida katab geomeetriline ornament (Sarvas 1987: 17).

Ruumtaieseid voolitakse puust ja savist, raiutakse kivist jne sõltuvalt materjalist ja taotlusest Metallitöötlemise põhimeetodid on sepistamine ja vormi valamine; pinda kaunistatakse kohrutuse, perforeerimise, graveerimise ning panus- (nt granuleerimine) ja katmistehnikate (emailimine) rakendamise teel. Seetõttu võib ruumiliste taieste hulgas materjali alusel eristada puu-, savi-, kivi- ja muid taieseid. Valmistamistehnika põhjal on mõttekas liigitada eriti metalltaieseid nt sepisteks ja valutaiesteks ehk valanditeks.

1. Skulptuure valmistati väga erinevast materjalist: puust, kivist, sarvest, luust, merevaigust, savist, metallist jm. Võib eristada monumentaal- ja pisiplastikat. Pisikujukesi on soome-ugri aladelt teada paleoliitikumist alates (vt V. Poikalaineni artiklit käesolevas kogumikus). Figuraal-skulpturaalsed on sageli ka mitmesugused ripatsid ja muud ehted. Näiteks Marimaalt on leitud pronksist inim-, imetaja- ja linnukujulisi ripatseid (VII-VI saj eKr), saapakujulisi ripatseid (II-III saj pKr), ažuurseid ehteid värvilis-

Joonis 5. Pronksiaegseid linnukujutisega puuanumaid Gorbunovo rabast Lõuna-Uuralist (Epohha bronzõ 1987: 401).

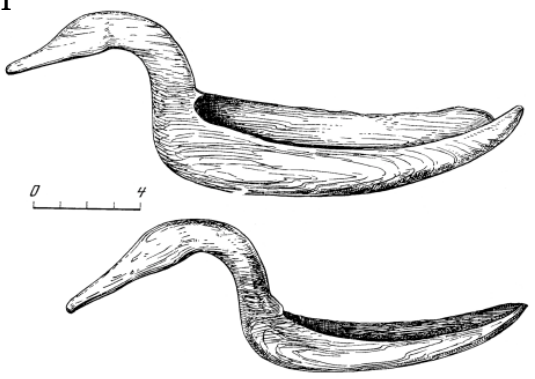


Joonis 6. Puuskulptuur Uuralitagusest Šigiri rabast (Mošinskaja 1976; joonis 10b).
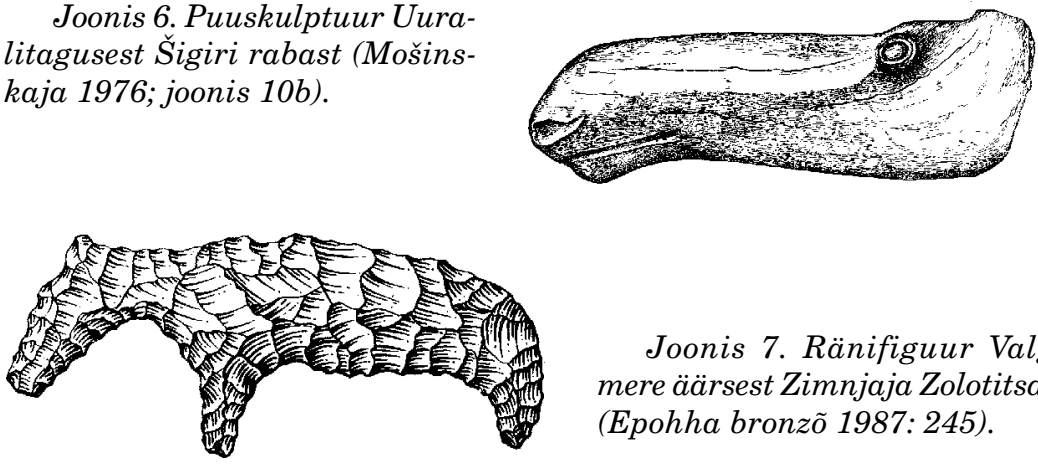

Joonis 7. Ränifiguur Valge mere äärsest Zimnjaja Zolotitsast (Epohha bronzõ 1987: 245).

test metallidest helisevate kellukjate ja hanejalgadest ripatsitega, samuti hobupeakujulisi ripatseid (5-11 saj) (RSFSR 1971: 487).

Mitmesugustel esemetel võib kohata skulpturaalseid kaunistusi, nt hantide ja manside juurest on leitud esimese aastatuhande keskpaigast pKr pärinevad ažuursed stiliseeritud karu-, jänese- ja põdrapeadega pronkspandlad. Skulpturaalsed kujutised on sageli seotud kultuslike puunõude (lusikad, kopsikud), sugukonna- ja hõimujuhtide atribuutide (sauad, sõjanuiad) ning luu- ja kiviriistade (karupea-, harvem põdrapeakirved, noad) käepidemetega. Tavaliselt on neil esemetel kujutatud vaid loomapead. Selliseid esemeid on teada Soomest (Laukaa, Pielisjärvi), Lätist (Sārnatest), Venemaalt (Oleni saar, Šigir, Gorbunovo (joonis 5)). Metalliajast pärinevad mitmekesise kaunistusega nn toredusrelvad, eriti mõõgad, millele oli graveeritud germaani päritoluga loomornament.

Ümarskulptuurid ehk -taiesed on skulptuurtaiesed, mille figuraalne kujutis on igast suunast vaadeldav. Soome-ugri aladelt on neid leitud arvukalt, kuid territoriaalse ja kronoloogilise ülevaate andmine pole käesoleva kirjutise ülesanne. Eriti sageli esineb veelindude, põtrade ja karude kujukesi, harvem madude ja inimeste omi. Neid on avastatud Ida-Baltikumist (Šventoji, Juodkrante, Tamula), Soomest (Pohjankuru, Säkkijärvi, Huittiset), Venemaalt (Oleni saar, Kubenino, Gorbunovo, Šigir) (Gorjunova 1978: 470; joonis 6). Soomeugrilastele olid iseloomulikud zoomorfsed ränikujukesed, mida on arvukalt leitud Ülem-Volgalt ja Okaa basseinist (Volossovo, Panfilovskaja Muromi lähedal), samuti Valge mere äärest (joonis 7). Permi ja läänesiberi loomastiili leviku alal esines ruumilisi (õõnsaid) metallist valatud loomakujusid (Oborin, Tšagin 1988). 


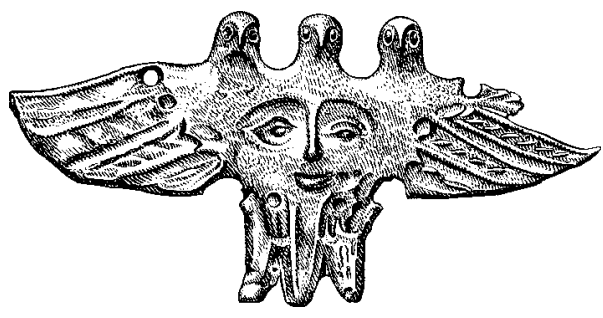

Joonis 8. Permi loomastiilis kolmepäise kotka kujutis (Gribova 1975: tahvel 6).

Joonis 9. Hobupäine plaatripats Terešino kurgaanist Volga ülemjooksult (Golubeva 1979: tahvel 18-19).

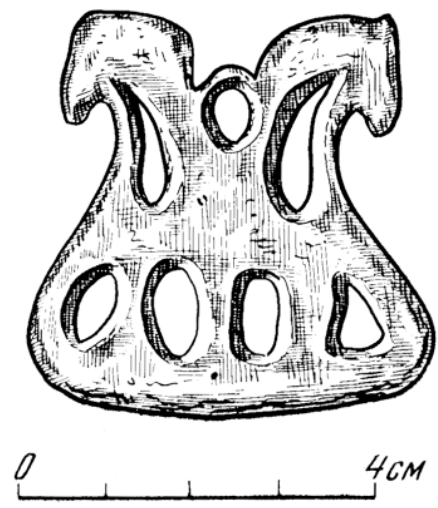

Reljeeftaiesed on mitmemõõtmelised figuraalsed või ornamentaalsed taiesed, mis on töödeldud vaid ühelt poolt. Siia kuuluvad permi ja läänesiberi loomastiilis pronksnaastud, näiteks röövlinnukujukesed, tiivad laiali ja inimese nägu rinnal (joonis 8). Reljeeftaiesed kuuluvad sageli ka plaattaieste hulka (vt allpool). Võib eristada kõrg- ja madalreljeefseid taieseid.

Plaattaiesed on õhukesed plaatjad esemed, mille kunstiefekti loob nende figuraalne või ornamentaalne välis- või sisekontuur. Siia kuuluvad mitmesuguse kujuga (näiteks ornitomorfsed) ripatsid, luust kammid, mille otsi kaunistavad hobusepead jne. Plaattaiesed sisaldavad sageli lame- ja reljeeftaide elemente ning mulgustamise ehk perforeerimisega tekitatud mitmesuguse kujuga väljalõikeid, mistõttu viimaseid nimetatakse ka pilu- ehk ažuurtaiesteks (joonis 9). Kui mulgustatud on riiet, nahka või mõnikord kasetohtu, on tegemist lametaiesega (vt eespool). Plaatjad võivad olla ka mõningad mitteskulptuursed esemed, mida ei maksa paigutada plaattaieste rühma.

2. Mitteskulptuurtaieste hulka kuuluvad väga mitmekesise ehituse ja kujuga mittefiguraalsed ehted, amuletid ja rõivakinnitid. Ehteid ja amulette kasutati ehtimiseks ja kaitsmiseks pahade vaimude eest, kuid sageli pole mainitud funktsioonid eristatavad. Neid kanti peamiselt ihul või rõivastel. Ehetel oli sageli samaaegselt nii rõiva kinnitamise, kaunistamise kui ka maagiline funktsioon. Kandmiskoha ja materjali alusel eristuvad pea- kaela-, käe- ja rõivaehted; luu-, metall- (hõbe-) jm ehted. Ent muinastaideteaduses 
on mõttekam neid klassifitseerida kuju ja (eriti metallehteid) vajadusel ka valmistamisviisi põhjal (vt eespool).

Eseme ehituse ja kuju järgi on käesolevasse rühma paigutatud:

1) võrutaiesed, mille hulka kuuluvad võrukujulised ehted, nagu pea-, kaela- käe- ja jalavõrud, oimurõngad, sõrmused, mitmesugused merevaigust ja kiltkivist rõngad, mis on paljudel juhtudel kokku keerutatud või punutud mitmest metalltraadist. Need võivad olla ka spiraalsed (spiraaltaiesed on valmistatud spiraali keeratud metallist, nende hulka kuuluvad eelkõige spiraalvõrud, -sõrmused ja vaselised (pronksspiraalid), kuid elemendina ka ehete ja rõivaste juurde kuuluvad spiraaltorukesed);

2) lülitaiesed koosnevad ühesugustest allosadest, mis moodustavad pikki, peenikesi ehteid. Nende seas on teokarpidest, kividest, helmestest või ripatsitest koosnevad keed, samuti ehteketid. Keedeks ühendatavad helmed võivad olla luust (nt linnu toruluudest), kivist, merevaigust, emailist, klaasist, hõbedast ja muust materjalist. Lülitaieste koostisosadeks olevad ripatsid võivad olla ümarskulpturaalsed, plaatjad, reljeefsed, müntidega jne. Neid valmistati hammastest, luust, merevaigust, kivist ja metallist;

3) muukujulised taiesed, nagu sõled, ehtenõelad, naastud, pandlad, tutulused (vööehted), mitmesugused ripatsid, võisid olla üpris keerulise ehitusega. Siinkohal sobib meenutada, et sõled on aegade vältel olnud väga erineva kujuga, mis on saanud nende liigitamise aluseks; nii eristatakse kärbis-, amb-, hoburaudsõlgi ja teisi tüüpe (vt Kirme 1986: 6 jj). Idapoolsed soomeugrilased kasutasid esimesel aastatuhandel ja teise aastatuhande alguses $\mathrm{pKr}$ rohkesti kõlisevaid "linnujalgadega" ripatseid (joonis 10). Muukujuliste mitteskulpturaalsete taieste hulka võib paigutada ka riietele kinnitatud mammu-

Joonis 10. Pronksist kõlisev hobupearipats Pjankovo kurgaanist Volga ülemjooksult (Golubeva 1979: tahvel 19-10).

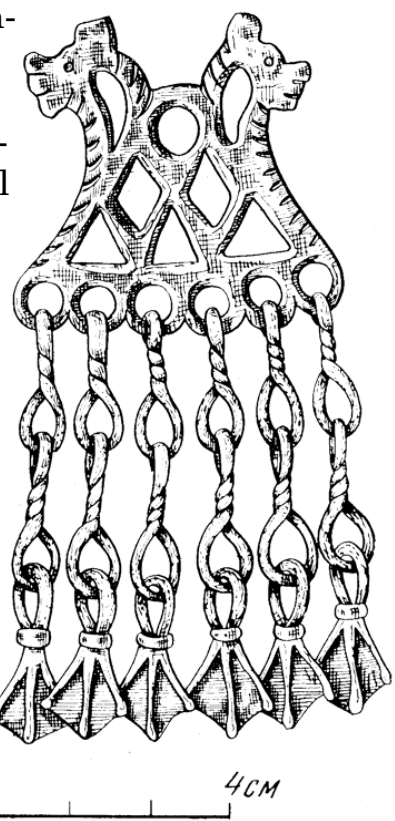




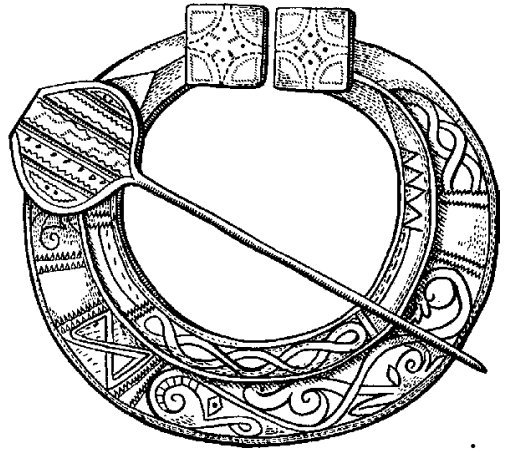

Joonis 11. Karjala pronkssõlg Kekomäelt Soome lahe äärest (Finnougrõ $i$ baltõ 1987: 262, tahvel 14-1).

tivõhast valmistatud helmed, mida on leitud näiteks noorema paleoliitikumi hauast Sungiris Vladimiri linnas.

Mainitud kolme rühma esemed sisaldavad mõnikord ka lametaiet neile kantud suhteliselt madalate figuraalkujutiste või ornamendi tõttu (joonis 11), samuti ümarskulpturaalseid elemente, näiteks teriomorfsete otstega sõlgedel.

Ehete-amulettide rühma tuleb tinglikult paigutada ka kihvad ja ilmselt religioosseil põhjustel riiete külge kinnitatud loomalõualuud, mida pole küll kunstipäraselt töödeldud.

\subsection{Muinasehitustaiesed}

Muinastaide alla kuulub muinasaegne ehituskunst, mis hõlmab nii üksikrajatisi kui ka nende kogumeid - asulaid (muinaskülad). Ehituskunst jagatakse tavaliselt funktsiooni alusel profaan-, sakraal- ja militaararhitektuuriks. Sama klassifikatsiooni saab projitseerida ka muinasaega.

Tinglikult paigutab siinkirjutaja muinastaide alla ka pühaks peetud loodusobjektid (pühad kivid, puud, allikad). Kuigi need pole inimkäte töö, on nad seotud mõtestatud tegevusega. Tähelepanuväärsed on taraga ümbritsetud looduslikud hiied ja pühad puud, kuid looduslikud pühamud ja pühaobjektid, nt kaljutaide loomise paigad, võisid olla ka kunstlike piireteta.

Profaanrajatiste hulka kuuluvad elamud, koldeasemed, majapidamishooned, tarad, veskid, kaevud jne. Hiljemalt vanema kiviaja keskmisel perioodil tekkisid juba asulad. Soome-ugri aladel ja naabruses rajati tollal elamute seinu mammutiluudest, kuid katused olid tõenäoliselt kaetud loomanahkadega, nt on sellise elamu jäänuseid leitud Komi territooriumilt Bõzovaja Petšora linna lähedal (RSFSR 1971: 483). Tavalisemad näivad olevat siiski puust ja nahkadega kaetud püstkojad ja muldonnid, mida rajati järjepide- 


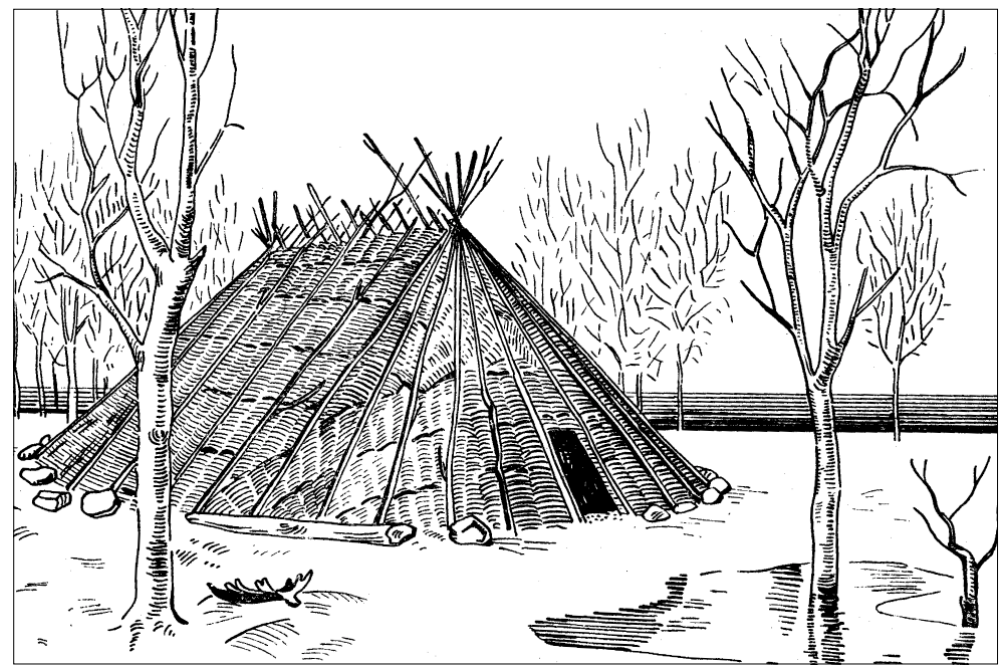

Joonis 12. Arheoloog Niina Gurina rekonstrueeritud neoliitiline Riigiküla I asula (Jaanits et al., 1982: 90).

valt ka hilisemal ajal (joonis 12). Koldeid tehti nii elamutesse kui ka eraldi asula territooriumile.

Baltimaadele ja mujale Euraasia metsavööndisse sai inimene elama asuda igijää taganemise järel alles mesoliitikumis ehk keskmisel kiviajal, mis kestis aastatel 11 400-5000 eKr. Neoliitikumis ehk nooremal kiviajal (V-II aastatuhandel eKr) ilmuvad mõnel pool metsavööndis roikaist alusel elamud (nt Ljalovo Moskvast 40 km põhja pool) ja vaiehitised (Modlona jõel Vologda oblastis). Modlona ääres ehitati nelinurkseid maju punutud seintega. II aastatuhandest $\mathrm{eKr}$ alates juurdus uus ehitustüüp - nelinurksed püstpalkidest seintega hooned, veelgi hiljem rõhtpalkidest seintega hooned (Raam 1975: 9). Soomes ehitati pronksiajal elamuks, aidaks ja loomalaudaks jagunevad pikad hooned, näiteks Nakkila Rieskaromäel põhiplaaniga $15 \times 4 \mathrm{~m}$; rauaajal ehitati veelgi suuremaid hooneid (Sarvas 1987: 21, 22). Muinaskülade suurus ja kuju sõltus olulisel määral ümbritsevast maastikust.

Seoses põllumajanduse tekke ja arenguga vajati spetsiaalseid rajatisi (rehi, laut jm). Aida esialgseks vormiks oli jahisaagi hoidmiseks kasutatav sammaslava. Muinasaega kuuluvad ka saunad ja kaevud ning võib-olla ka veskid. Hiljemalt I aastatuhande teisel 


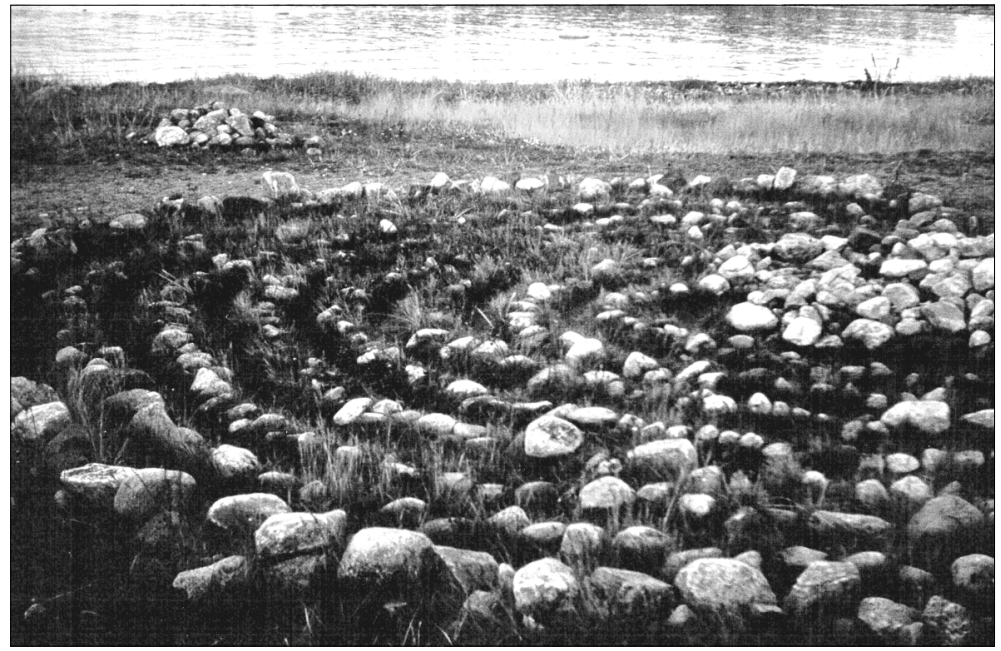

Joonis 13. Kivilabürint Solovetsi saartelt. E. Ernitsa foto.

poolel pKr hakkas eestlastel ja vadjalastel kujunema omapärane taluehitis - rehielamu (Viires 1995: 233-234).

Sakraalrajatiste hulka kuuluvad hauarajatised (kääpad, kivikirstkalmed, laevkalmed, tarandkalmed jm surnute majad), labürindid jm (joonis 13). Tuntud mesoliitilised kalmistud soome-ugri aladel asuvad Oleni saarel Äänisjärve (Onega) keskel ja Zveijnikis Põhja-Lätis. Hauarajatised muutusid silmapaistvaks pronksiajal. Soomes rajati pronksiajal sadadest ja tuhandetest munakividest koosnevaid hauamonumente, nt üks (1) selline on teada Perniö Lampolast (Sarvas 1987: 21). Eestis tekkisid hilisel pronksiajal kivikuhjad ehk kangrud ja laevakujulised kivikalmed, milles paiknes üks või mitu kivikirstu. Hiljem hakati rajama tarandkalmesid,

Joonis 14. Pisiait pühapaigas Põhja-Sosva jõgikonnas Lääne-Siberis (Mošinskaja 1976: joonis 7b). 


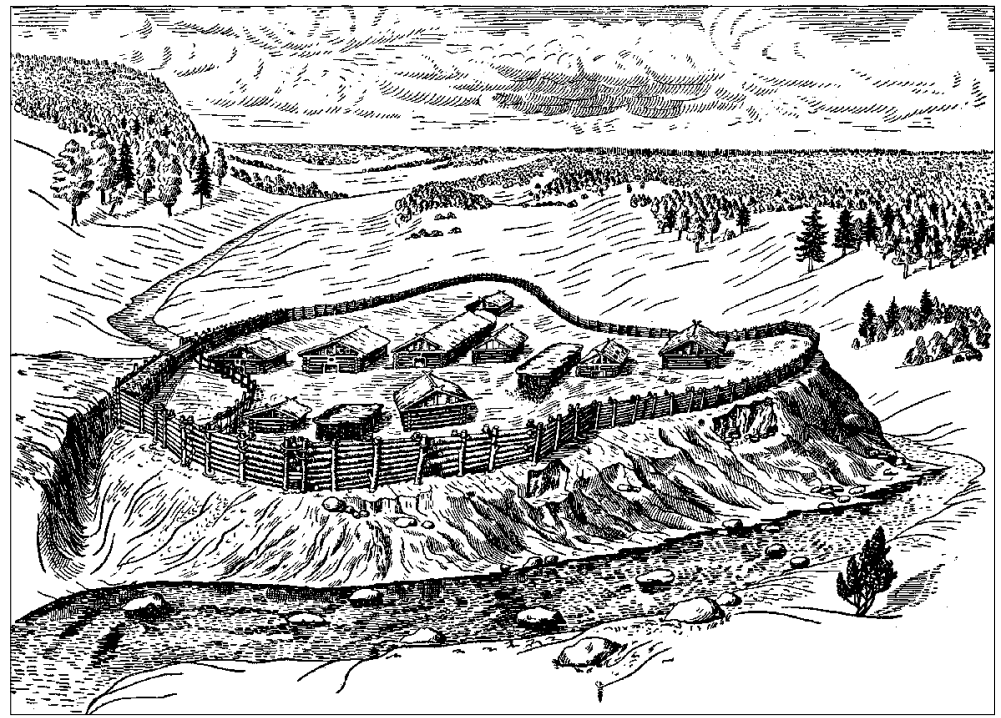

Joonis 15. Merjalaste kindlustatud asula Bereznajakis (I aastatuhat pKr). (Finno-ugrõ i baltõ 1987: 273, tahvel 25-3).

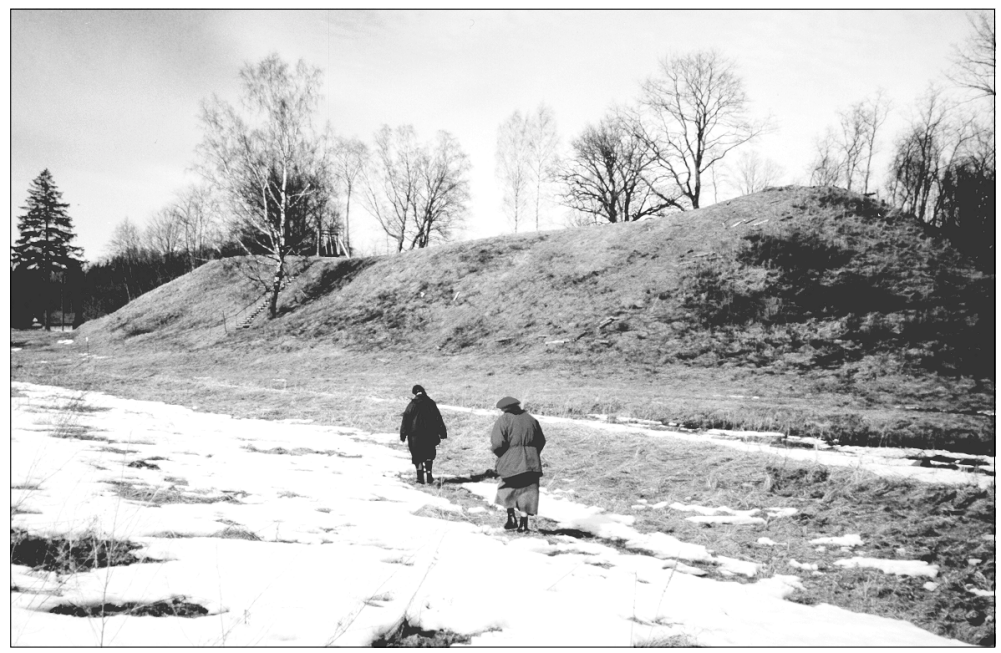

Joonis 16. Alatskivi Kalevipoja säng. Linnamägi (I aastatuhande lõpp eKr-XII sajand pKr). E. Ernitsa foto. 
nt Tõraveres Tartumaal ja Virunukas Võru maakonnas. Need koosnesid mitmest mulla või kividega täidetud nelinurksest kividest laotud tarandist. Nende kogupikkus võis ulatuda isegi 100 meetrini (Jaanits et al. 1982: 149-151). Oletatakse, et nii kangrud kui ka tarandkalmed võisid muinaselanike kujutelmades olla surnute elamud (Raam 1975: 10). Sakraalehitiste hulka kuuluvad ka hooned pühapaikades, näiteks obiugrilaste sammastel pisiaidad (joonis 14).

Militaarrajatiste hulka võib paigutada puust või kividest tara ja/või muldvalliga ümbritsetud kindlustatud asulad, linnused ehk linnusasulad, mis olid tegelikult polüfunktsionaalsed. Sellised asulad tekkisid soome-ugri aladel pronksiajal (nt Asva ja Ridala Saaremaal ning asulad Djakovo kultuuri alal tänapäeva Moskva piirides). Kaitsefunktsiooni täitsid eriti mitmesuguse konstruktsiooniga tarad ja vallid (joonised 15 ja 16). Meie ajaarvamise esimesel aastatuhandel on tekkinud suhteliselt väikesed linnused ülikute peredele (nt Eestis Lembitu kants Lõhaveres Viljandimaal).

\section{Kirjandus}

Epohh bronzõ 1987 = Epohha bronzõ lesnoi polosõ SSSR. Moskva: Arheologija SSSR.

Finno-ugrõ i baltõ 1987 = Finno-ugrõ $i$ baltõ v epohhu srednevekovja . Moskva: Arheologija SSSR.

Flood, J. 1997. Rock Art of the Dreamtime. Images of Ancient Australia. Sydney: Angus \& Robertson.

Gorjunova, J. 1978. Ugro-finnõ. Iskusstvo stran i narodov mira 4. Moskva, lk 469-472; asjaomane kirjandus lk 472.

Gribova, L. 1975. Permski zverinõi stil. Problemõ semantiki. Moskva.

Helskog, K. 1994. The Rock Carvings in Hjemmeluft/Jiepmaluokta. Alta.

Jaanits, L. \& Laul, S. \& Lõugas, V. \& Tõnisson, E. 1982. Eesti esiajalugu. Tallinn.

Kangilaski, J. 1997. Üldine kunstiajalugu. Tallinn.

Kirme, K. 1986. Eesti sõled. Tallinn.

Mošinskaja, V. I. 1976. Drevnjaja skulptura Urala v Zapadnoi Sibiri. Moskva.

Okladnikov, A. P. \& Petrin, V. 1983. Paleolititšeskije rissunki Ignatijevskoi peštšerõ na Južnom Urale: predvaritelnaja publikatsija. Plastika i rissunki drevnihh kultur. Novosibirsk, lk 47-58.

Oborin, V. \& Tšagin, G. 1988. Iskusstvo Prikamja. Tšudskije drevnosti Rifeja. Permski zverinõi stil. Perm.

Ošibkina, S. 1997. Veretje I. Poselenije epohhi mezolita na Severe Vostotšnoi Jevropõ. Moskva. 
Pankrušev, G. 1978. Mezolit i neolit Karelii 2. Neolit. Leningrad.

Poikalainen, V. \& Ernits, E. 1996. Esihistoriallista kalliotaidetta Venäjän suomalais-ugrilaisilta alueilta. Löytöpaikat ja ongelmat. Historia Fenno-Ugrica. Congressus primus historiae Fenno-Ugricae I: 2. Oulu, lk 217-229.

Poikalainen, V. \& Ernits, E. 1998. Rock Carvings of Lake Onega. The Vodla Region. Tartu.

PSSSR 1984 = Paleolit SSSR. Boriskovski, P. (toim). Moskva: Nauka.

Raam, V. 1975. Eestlaste muistne ehituskunst. Eesti kunsti ajalugu 1. Eesti kunst kõige varasemast ajast kuni 19. saj. keskpaigani. Tallinn, lk 9-13.

RSFSR 1971 = Rossiiskaja Sovetskaja Federativnaja Sotsialistitšeskaja Respublika (RSFSR). Iskusstvo stran i narodov mira 3. Moskva, lk 301767.

Rudenko, K. 1996. Metal Ware of the Finno-Ugric Peoples of Eastern Europe and the Transurals. Historia Fenno-Ugrica. Congressus primus historiae Fenno-Ugricae I: 2. Oulu, lk 299-309.

Sarvas, P. 1987. Esihistoriallinen taide. Suomen taide 1. Keuruu.

Selirand, J. 1975. Luunikerdus, keraamika, metallehistöö. Eesti kunsti ajalugu 1. Eesti kunst kõige varasemast ajast kuni 19. saj. keskpaigani. Tallinn, lk 13-20.

Tvauri, A. 1999. Cup-marked Stones in Estonia. Folklore 11, lk 113169.

Viires, A. 1995. Eesti rahvakultuuri leksikon. Tallinn. 